Angelina Raičković

Arheološki institut Beograd

araickovic@yahoo.com

Sonja Vuković

sonja.vukovic@gmail.com

UDK 904:738.8(497.11)"01/02"

Izvorni naučni članak

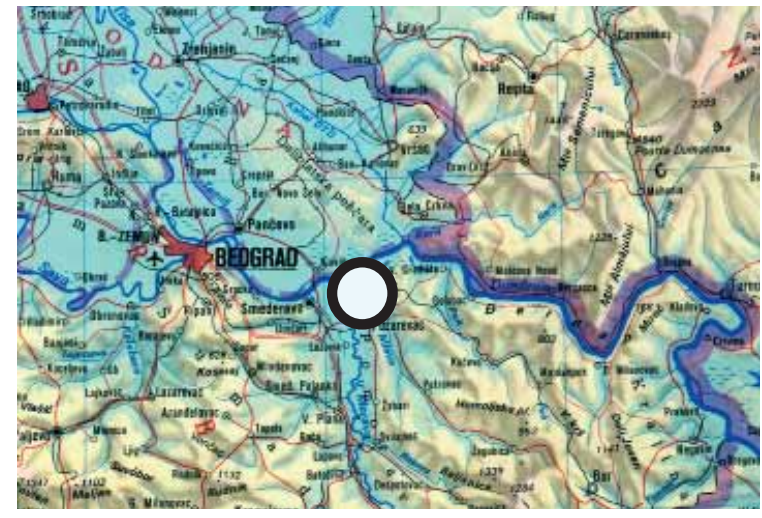

Viminacium, Stari Kostolac, Srbija

LAT 44 44' 09'" / LONG 21 12' 42"

\title{
KERAMIČARSKA PEĆ SA ISTOČNE NEKROPOLE VIMINACIJUMA
}

\begin{abstract}
APSTRAKT
Na lokaciji Kod Koraba, na prostoru Istočne nekropole Viminacijuma, pored skeletnih i kremiranih grobova, otkrivena je i jedna grnčarska peć. Iako je peć bila oštećena radom mehanizacije, njeno istraživanje je pružilo značajne podatke, pošto su u ložištu pronađeni fragmenti keramičkih posuda $i$ životinjske kosti. Peć je datovana u period od početka II do prve polovine III veka, što se poklapa sa vremenom korišćenja nekropole.
\end{abstract}

KLJUČNE REČI: KERAMIČARSKA PEĆ, KERAMIKA, NAČIN OBRADE, ŽIVOTINJSKE KOSTI, NEKROPOLA, VIMINACIJUM.

\section{UVOD}

Lokacija Kod Koraba nalazi se na prostoru Istočne nekropole Viminacijuma, oko $650 \mathrm{~m}$ jugoistočno od legijskog logora. Zbog napredovanja površinskog kopa uglja Drmno, u periodu od 2005 - 2008. godine vršena su zaštitna arheološka iskopavanja. ${ }^{1}$ Tom prilikom otkriveno je 79 grobova sa skeletnim i 132 groba sa ostacima spaljenih pokojnika. Nalazi grobova ukazuju da je pomenuta lokacija predstavljala nekropolu, koja se prostire istočno od grada Viminacijuma. Grobovi su datovani u period od druge polovine I do druge polovine III veka, sa izuzetkom jednog groba koji je datovan u IV vek. ${ }^{2}$ Prilikom rada bagera

1 Radove je izvodio Arheološki institut iz Beograda pod rukovodstvom dr M. Koraća, naučnog savetnika Arheološkog instituta.

2 Bogdanović, u pripremi tokom 2008. godine, u profilu površinskog kopa, u blizini grobne konstrukcije od kamenih ploča, konstatovana je grnčarska peć. U ovom radu su, uz opis peći, predstavljeni i nalazi iz njenog ložišta: keramičke posude i životinjske kosti.

\section{KERAMIČARSKA PEĆ}

Peć je bila izuzetno oštećena mehanizacijom. Zidovi kalote su sačuvani od nivoa rešetke u visini od $0.65 \mathrm{~m}$, a sama rešetka sa cilindričnim, radijalno raspoređenim otvorima nazire se u profilu. Centralni nosač rešetke peći konstatovan je samo u svojoj temeljnoj zoni. Debljina rešetke je $0.30 \mathrm{~m}$, širina rosta $0.35 \mathrm{~m}$, dok visina od poda do rosta iznosi $0.60 \mathrm{~m}$. Budući da se peć nalazila uz samu ivicu površinskog kopa (slike broj 1 i 2), iz bezbednosnih razloga je u jugozapadnoj strani lo- 


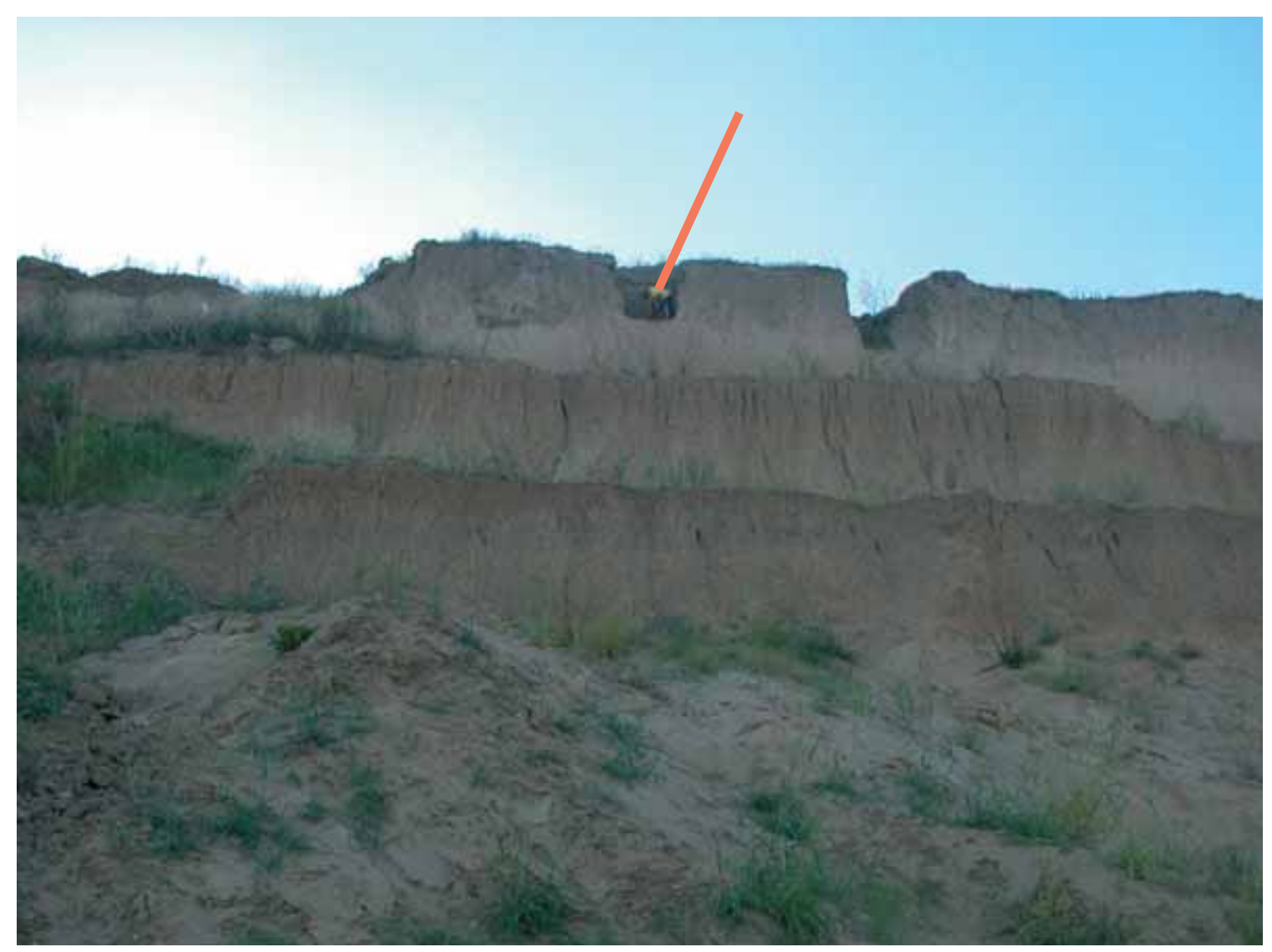

Slika broj 1 - Položaj otkrivene peći na ivici površinskog kopa "Drmno"

žišta istražen samo deo u dužini od $0.40 \mathrm{~m}$. Otvori za strujanje vazduha neophodnog za gorenje po pravilu su identične veličine čiji prečnik varira od 0.07 do $0.12 \mathrm{~m}^{3}$, dok je u slučaju ove peći taj otvor $0.08 \mathrm{~m}$ (plan broj 1). ${ }^{4}$ Peći ovog tipa otkrivene su i na prostoru Zanatskog centra, gde su bile zidane od opeka i tegula. Kod ove peći to nije moguće utvrditi jer je sačuvan samo deo od nabijene zapečene zemlje.

\section{KERAMIČKI MATERIJAL IZ LOŽIŠTA PEĆI}

(slika broj 3)

Plitka zdela ${ }^{5}$ sa kratkim, blago iskošenim i po ivici zaravnjenim obodom i blago zaobljenim zidovima trbuha koji se lome i skoro horizontalno spuštaju ka uskoj prstenastoj stopi. Rađena je

3 Raičković 2007, 12.

4 Crtež arhitekte E. Nikolić.

5 Raičković 2007, T. II sl. br. 21. od srednje prečišćene gline crvene boje pečenja, spoljne površine bojene tonovima mrke boje.

Pronađeni lonci u ložištu ove peći su najraznovrsniji po tipovima. Izdvaja se lonac horizontalno razgrnutog ${ }^{6}$ i sa unutrašnje strane užljebljenog oboda koji se spušta ka visoko postavljenom trbuhu i ravnom dnu. Rađen je od peskovite gline, mrkosive boje pečenja i neobrađene spoljašnje površine. Konstatovan je i lonac horizontalno izvučenog, ${ }^{7}$ pri krajevima blaže uvijenog oboda naglašenog kratkog vrata i bikoničnog trbuha koji se spušta ka ravnom nenaglašenom dnu. Rađen je od peskovite gline u sivoj boji pečenja i neobrađene spoljašnje površine. Potom sledi i lonac horizontalno razgrnutog i kratkog oboda, ${ }^{8}$ stanjenog pri vrhu, sa debelim zidovima trbuha koji se spuštaju ka ravnom nenaglašenom dnu. Rađen je od srednje prečišćene gline crvene boje pečenja i neobrađene spoljašnje površine. Javlja se i lonac

\footnotetext{
6 Raičković 2007, T. V sl. br. 44.

7 Raičković 2007, T. V sl. br. 52.

8 Raičković 2007, T. V sl. br. 53.
} 


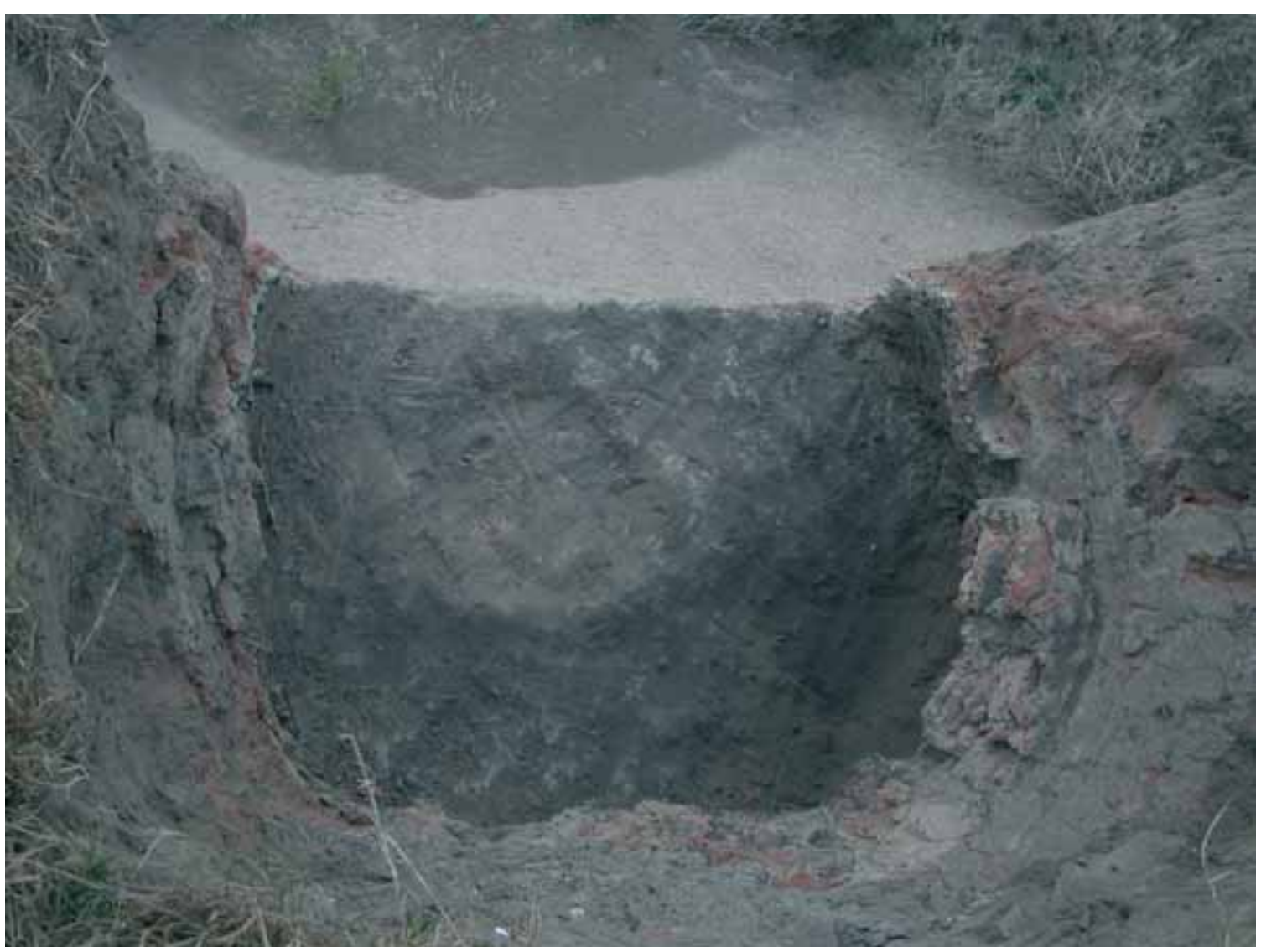

Slika broj 2 - fotografija osnove peći

trakasto profilisanog na ivici zaravnjenog oboda, ${ }^{9}$ sa unutrašnje strane užljebljenog. Ispod oboda polazi trakasta drška koja je sa strane užljebljena. Bikoničan trbuh u gornjem delu ukrašen je plitkim žljebom. Rađen je od peskovite gline sive boje pečenja i neobrađene površine. Zatim lonac koso izvučenog oboda i vrećastog trbuha, ${ }^{10}$ rađen od peskovite gline sive boje pečenja i neobrađene površine, dok je dekoracija izvedena urezivanjem. Sledi veći lonac prstenasto profilisanog, sa unutrašnje strane užljebljenog oboda i jajolikog trbuha, ${ }^{11}$ rađen od peskovite gline sive boje pečenja i neobrađene površine.

Tanjiri su zastupljeni oblikom sa blago uvučenim neprofilisanim obodom, iskošenim zidovima trbuha koji se povijaju prema užem prstenastom dnu. ${ }^{12}$ Jedan od njih izrađen je od srednje prečišćene gline crvene boje pečenja i crveno

9 Raičković 2007, T. VI sl. br. 56.

10 Raičković 2007, T. VI sl. br. 60.

11 Raičković 2007, T. VI sl. br. 62.

12 Raičković 2007, T. VIII sl. br. 64. bojene površine, a drugi tanjir istog tipa je od srednje prečišćene gline sive boje pečenja čija je spoljna površina bojena crnom bojom.

Od ostalih oblika mogu se izdvojiti poklopci koji su u ovoj celini i najbrojniji iako su zastupljeni samo sa dva tipa. Jedan od njih je sa zaobljenim obodom ${ }^{13}$ čiji se zidovi trbuha koso spuštaju ka dugmetastoj dršci. Različitih su dimenzija i mrke ili sive boje pečenja, a zemlja od koje su izrađeni je srednje prečišćena ili peskovita. Ovaj tip poklopca se i inače najbrojnije javlja na drugim istraživanim lokacijama na Viminacijumu. Drugi tip poklopca koji je otkriven u ložištu ove peći pripada tipu većeg i dubljeg poklopca sa prstenasto profilisanim obodom i zidovima koji se zaobljeno spuštaju ka dnu. ${ }^{14}$ Rađeni su od peskovite gline, mrke ili sive boje pečenja, a spoljašnja površina im je neobrađena.

Pehari su u ovoj celini zastupljeni sa dva tipa. Jedan od njih je sa bikoničnim, koso raz-

13 Raičković 2007, T. XI sl. br. 104.

14 Raičković 2007, T. XI sl. br. 108. 


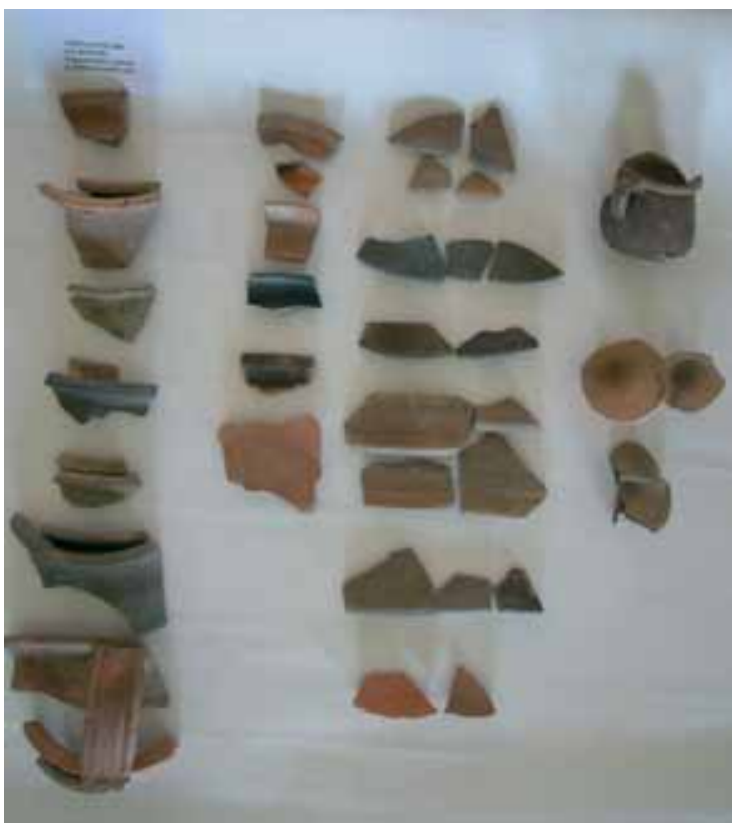

Slika broj 3 - fragmenti keramičkih posuda nađeni u ložištu peći

grnutim, kratkim obodom i prstenastim dnom sa jednom drškom, koja polazi od oboda i spaja se na trbuhu. ${ }^{15}$ Rađen je od crvene, srednje prečišćene gline. Površina je bojena tonovima mrkocrvene boje. Drugi tip pehara je sa koso izvučenim i kratkim obodom, jajolikim trbuhom koji se spušta ka uskom ravnom dnu. ${ }^{16}$ Ova vrsta pehara rađena je od peskovite gline beložućkaste boje pečenja i neobrađene spoljne površine.

$\mathrm{Na}$ keramičkom materijalu pronađenom u ložištu peći nema tragova gorenja. Ono što se može primetiti jeste da ima primeraka deformisanih posuda. Po oblicima najbrojniji su fragmenti lonaca, slede poklopci i tanjiri. Posude su rađene od srednje prečišćene gline crvene ili sive boje pečenja, kao i od gline peskovite fakture u crvenoj ili sivoj boji pečenja. Od ornamenata korišćena je radla za ukrašavanje dna bojenog tanjira i za nekoliko fragmenata sivog peskovitog lonca, a na nekoliko fragmenata se javljaju i plića rebra. Konstatovano je ukupno 256 fragmenata keramike od kojih su najbrojniji fragmenti rađeni od srednje prečišćene i peskovite gline, neobrađene spoljne površine. Poređenjem ovih oblika sa materijalom koji je otkriven u ložištima i jamama u okviru peći iz Zanatskog centra može se konstatovati da

15 Raičković 2007, T. XIII sl. br. 116. 16 Nikolić - Đorđević 2000, 171, tip IX/35. su ovi oblici uglavnom bili otkriveni u otpadnim jamama i u pećima br. 1,2 i $3 .{ }^{17}$

U ložištu je pored keramičkog konstatovan i koštani materijal.

\section{ŽIVOTINJSKE KOSTI}

(slike broj 4, 5, 6)

Pored kermičkih posuda u ložištu peći je otkriven i manji broj životinjskih kostiju. Pronađeno je osam primeraka kostiju krupnih i srednjekrupnih sisara, od kojih sedam primeraka pripada domaćem govečetu (Bos taurus), dok jedna kost pripada srni (Capraeolus capraeolus). Među kostima govečeta nalazi se šest fragmentovanih leđnih pršljenova, koji najverovatnije pripadaju istoj jedinki, kao i 1 fragment vertikalne grane mandibule. Na pršljenovima su vidljive linije srastanja kranijalne i kaudalne zglobne površine. Može se pretpostaviti da je jedinka govečeta bila starosti do 5 godina, budući da u tom periodu srastaju epifize pršljenova. ${ }^{18}$

$\mathrm{Na}$ mandibuli se sa lingvalne strane nalaze tri ureza, koji predstavljaju tragove kasapljenja. Srna je predstavljena fragmentom dijafize metatarzalne kosti. Na ovom metatarzusu, kao i na jednom od fragmenata pršljenova nalaze se tragovi glodanja pasa. Kosti su, uglavnom, dobro očuvane, a na dva pršljena primetni su tragovi raspadanja koje je uzrokovano fizičko-hemijskim uslovima kojima je bila izložena kost. Iako bi se očekivalo, na kostima nije bilo tragova gorenja.

Zbog prisustva životinja koje su korišćene u ishrani i tragova kasapljenja, fauna pronađena u ložištu ove peći bi mogla predstavljati ostatke hrane.

\section{ZAKLJUČAK}

Nalazi iz ložišta grnčarske peći, fragmentovane keramičke posude i životinjske kosti, na kojima nije bilo tragova gorenja, ukazuju na činjenicu da su deponovani nakon perioda korišćenja same peći. Uzrok napuštanja peći nije moguće sa sigurnošću utvrditi, ali se može pretpostaviti da je do napuštanja došlo usled urušavanja rešetke peći.

17 Raičković 2007, 104 - 106.

18 Silver 1969, 285. 
Na osnovu analogija sa materijalom sa drugih lokacija na Viminacijumu, ali i širom Gornje Mezije, ${ }^{19}$ keramički materijal iz ložišta peći datuje se u period od početka II do sredine III veka. Sam izgled keramičarske peći ne podleže osetljivijem datovanju, jer ova peć po svojim karakteristikama pripada najbrojnije zastupljenom tipu peći koje se javljaju od II do IV veka na prostoru Gornje Mezije.

Grnčarske peći konstatovane su i na viminacijumskoj nekropoli "Pećine", ${ }^{20}$ kao i na nekropolama Singidunuma ${ }^{21}$ i Sirmijuma. ${ }^{22} \mathrm{Na}$ navedenim lokalitetima peći su nalažene u grupi, kao zanatski centri. Njihova funkcija je bila usmerena ka produkciji posuda za funerarne rituale. ${ }^{23}$ Može se pretpostaviti da je na Istočnoj nekropoli Vimiacijuma takođe postojao veći broj peći.

Grnčarska peć sa lokacije Kod Koraba predstavlja najistočniji nalaz grnčarskih peći na Viminacijumu, koji je uz sve osobine velike antičke metropole, potvrđen i kao veliki proizvodni grnčarski centar.

\section{LITERATURA}

\section{Bogdanović u pripremi}

I.Bogdanović, Rezultati arheološko - geofizičkih istraživanja na lokalitetu "Kod Koraba" (Istočna nekropola Viminacijuma). Arheologija $i$ prirodne nauke 5 . u štampi.

\section{Голубовић 2008}

Голубовић, С., Извештај о археолошким истраживањима на локацији Код Кораба (Виминацијум). Археолошки преглед 2-3, нова серија (2005/2006), 2008, 46-50.

\section{Милошевић 2001}

П. Милошевић, Археологија и историја Сирмијума, Нови Сад 2001.

\section{Nikolić-Đorđević 2000}

S. Nikolić-Đorđević, Antička keramika Singidunuma, Singidunum II, Beograd 2000, 11 -244 .

\section{Raičković 2007}

A. Raičković, Keramičke posude Zanatskog centra iz Viminacijuma, Arheologija i prirodne nauke posebna izdanja 3, Beograd 2007.

\section{Silver 1969}

IA Silver, The ageing of domestic animals, u pp. 283 - 302 Science in Archaeology (D. Brothwell \& E. Higgs (eds.)). London 1969: Thames and Hudson

\section{Cvjetićanin 2000}

T. Cvjetičanin, Grnčarska radionica u Singidunumu - lokalitet Narodno Pozorište, Singidunum 2, Beograd 2000, 245 - 254.

\section{POTTERY KILN FROM THE EASTERN NECROPOLIS OF VIMINACIUM}

The kiln for pottery firing, besides graves with inhumation or cremation, was found at the site "Kod Koraba" which belongs to the eastern necropolis of Viminacium. The research gave us very important data concerning the kiln that was seriously damaged by the work of heavy machines. Inside furnace a lot of fragments of various ceramic vessels and animal bones were found. The kiln is dated into period from the beginning of II till the middle of III century A.D. which responds to the period of burials at necropolis.

KEY WORDS: POTTERY KILN, POTTERY, PRODUCTION PROCESS, ANIMAL BONES, NECROPOLIS, VIMINACIUM.

19 Nikolić-Đorđević 2000, 11 - 244.

20 Raičković 2007, 11.

21 Cvjetičanin 2000, 253.

22 Milošević 2001, 91.

23 Cvjetićanin 2000, 253. 


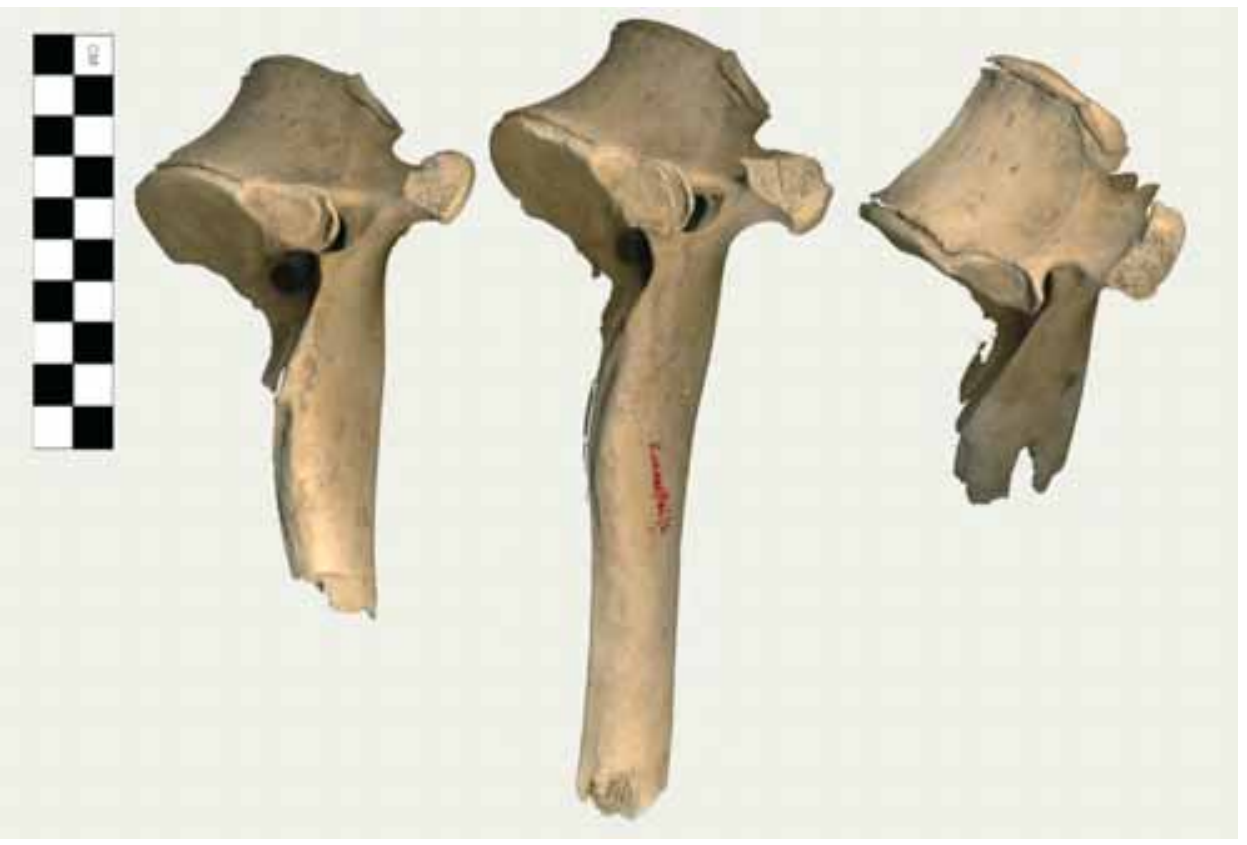

slika broj 4. Leđni pršljenovi domaćeg govečeta

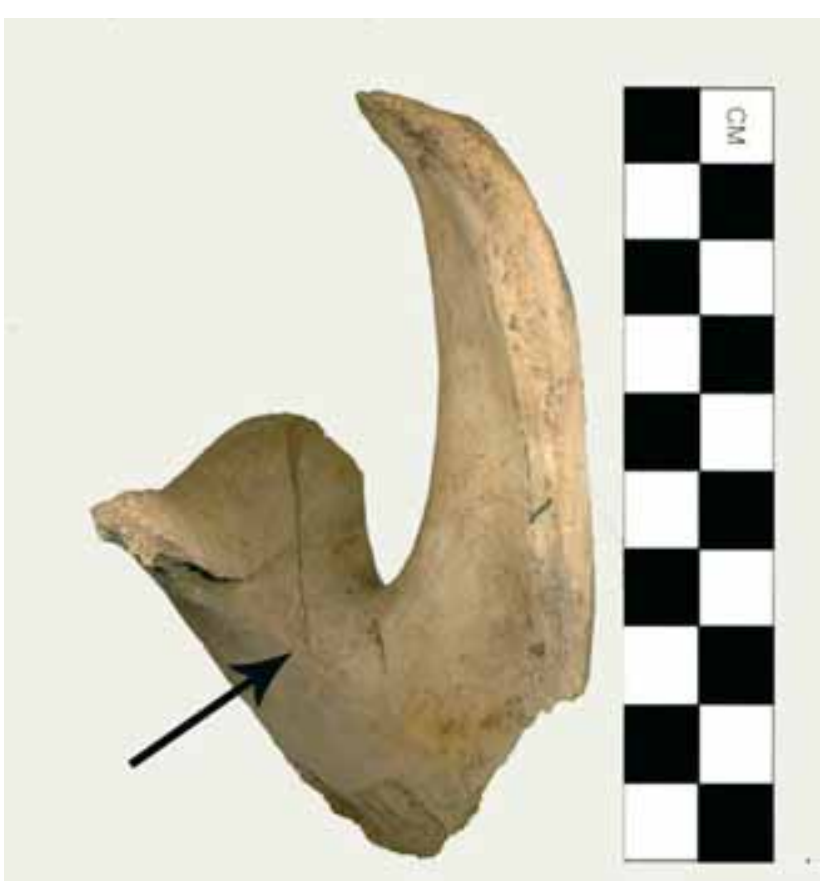

Slika broj 5. Mandibula govečeta, lingvalna strana (strelica pokazuje tragove kasapljenja)

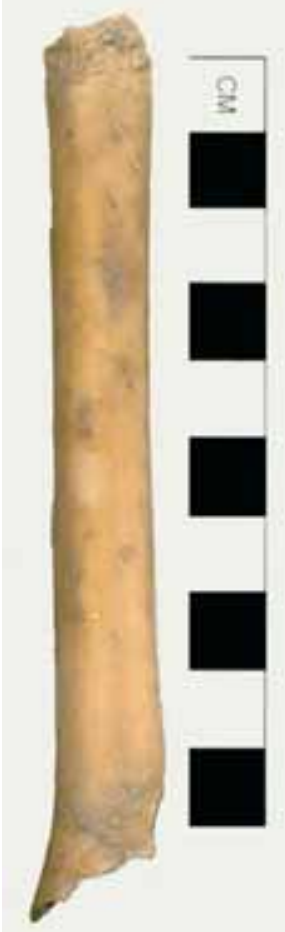

Slika broj 6. Metatarzus srne 


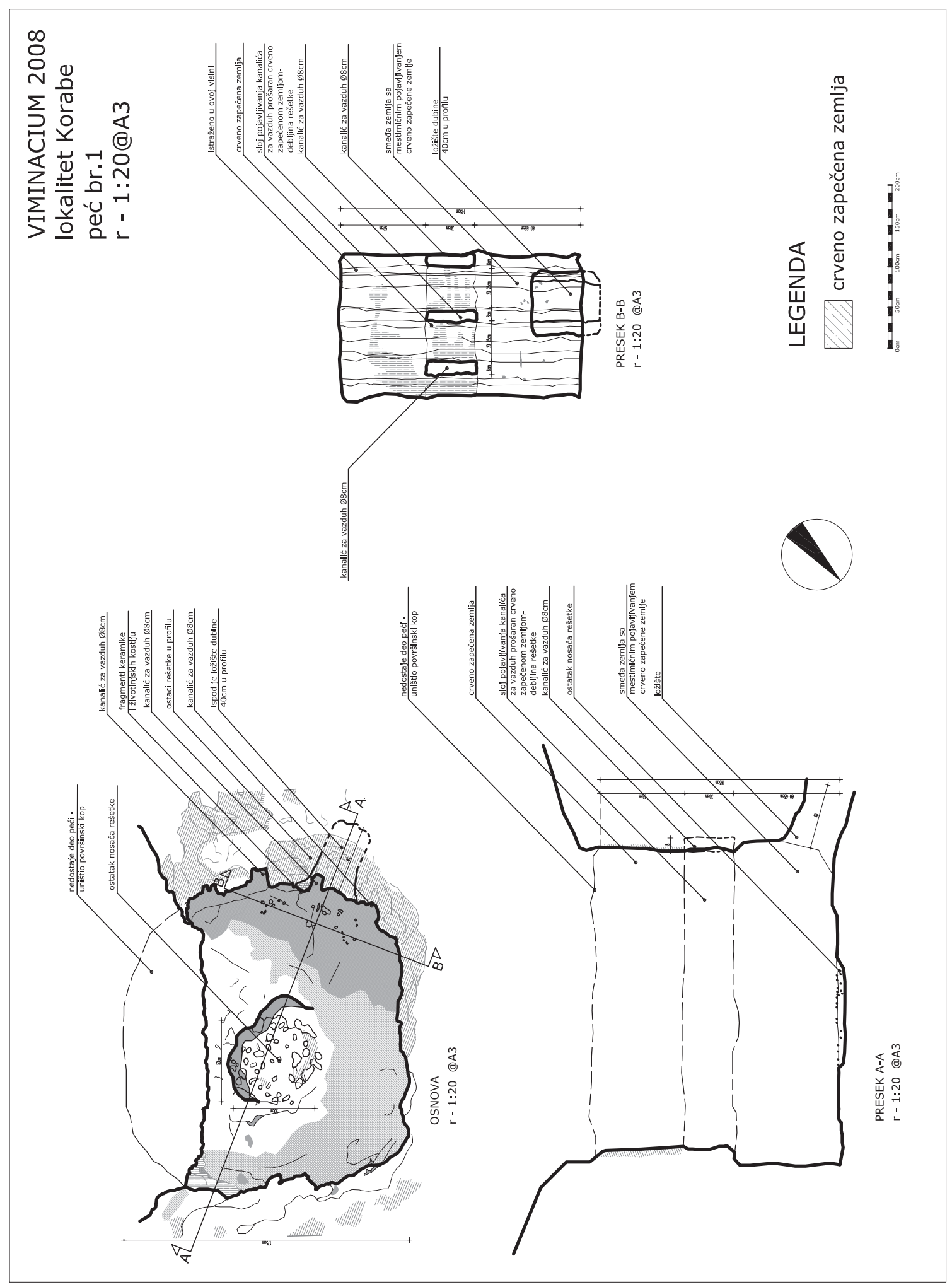

Plan broj 1. Peć broj 1, lokalitet Kod Koraba 